\title{
Relationship between texture and cell-wall components of safou (Dacryodes edulis (G. Don) H.J. Lam) fruits at different storage conditions
}

\author{
Bayi Reine DOSSOU1,2*, Crépin ELLA MISSANG², Simplice Damintoti KAROU1*, Yaovi AMEYAPOH ${ }^{1}$ \\ 1: Laboratoire de Microbiologie et de Contrôle de Qualité des Denrées Alimentaires (LAMICODA), Ecole Supérieure des \\ Techniques Biologiques et Alimentaires (ESTBA), Université de Lomé, BP 1515, Lomé, Togo. \\ 2: Unité de Recherche Agrobiologie, Université des Sciences et Techniques de Masuku Gabon, B.P. 941, Masuku \\ Franceville. \\ *Corresponding author: simplicekarou@hotmail.com
}

Original submitted in on $12^{\text {th }}$ February 2018. Published online at www.m.elewa.org on 31st May 2018 https://dx.doi.org/10.4314/jab.v125i1.6

\begin{abstract}
Objective: The objective of this study was to determine the relationship between texture and cell wall component of safou (Dacryodes edulis (G Don) HJ Lam) at different storage conditions during the safou softening.

Methodology and results: Using a General Linear Model (GLM), statgraphic software plus v. 5. 0 and XLstat 2007software, the relationship between texture and cell wall component of safou at different storage conditions was evaluated. At different stages of ripeness, safou were picked and stored in different conditions including: cultivar, picking mode, packaging mode and temperature. For each condition, texture, water loss, alcoholinsoluble CDTA- soluble pectins and neutral sugar level and methoxylation degree were measured.

The results showed that the temperature and method of storage and theirs interaction influenced significantly the texture of the safou during storage. Softening and dehydration through transpiration are the two processes that changed the safou texture at high temperature $\left(28^{\circ} \mathrm{C}\right.$ and $\left.36^{\circ} \mathrm{C}\right)$. The cultivar and the maturity stage also influenced significantly the texture. The correlation between texture and cell-wall component including alcohol insoluble solids, CDTA soluble pectin extracts, rhamnose and arabinose were very high. MIA (Materiel Insoluble in Alcohol) content increased and galacturonic acid content of CDTA Soluble Pectin extracts decreased, depending on the maturity level of safou: the degradation of homogalacturonans of pectins during the safou softening.

Conclusion and application of results: the degradation of homogalacturonans of safou pectins had an impact on their texture. Therefore, for their postharvest shelf life, safou must be stored at low temperature $\left(18^{\circ} \mathrm{C}\right)$ with or without packing.
\end{abstract}

Keywords: Safou, texture, pectins, softening, Dacryodes edulis 


\section{INTRODUCTION}

For practically all consumed pulpy fruits species, ripening process confers desirable organoleptic and nutritional characteristics such as chemical composition, vitamins, flavour, colour and texture. Among the organoleptic characteristics, texture is considered as major quality attribute of fruits having a significant commercial and economic importance (Giovannoni, 2011). Nevertheless, excessive fruit softening during ripening limits postharvest shelf life and transportability by increasing physical damages during handling and susceptibility to diseases (Goulao and Oliveira, 2008). Dacryodes edulis (G Don) HJ Lam) fruit (figure 1), locally called safou, is a very important nutritional and socio-economical crop in Central Africa and countries bordering the Gulf of Guinea (Kengue, 1990; Silou et al., 2002; Schreckenberg et al., 2002).

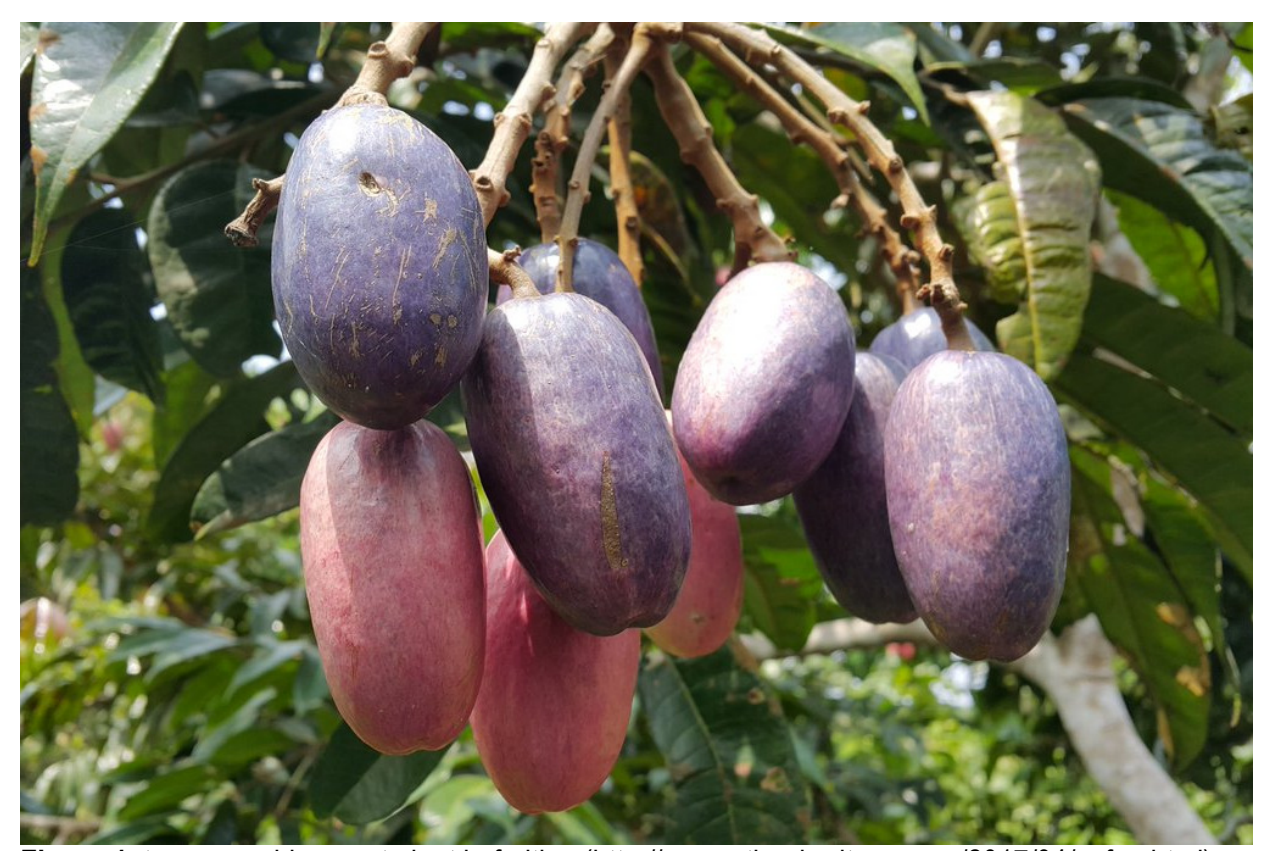

Figure 1: two-year-old marcot plant in fruiting (http://www.ethnoheritage.com/2017/04/safou.html)

However, after picking, safou fruits undergo exceptionally rapid softening at ambient temperature, thus altering their edible and commercial qualities and limiting export. Several practices including picking mode and storage conditions have been tried in order to extend safou shelf life but the results are in general unsatisfactory. (Kengue, 2002) The development of rational and effective approaches to improve safou preservation and quality depends on understanding the biological basis of safou softening. Softening is a consequence of cell wall disassembly during the ripening process. Cell wall polysaccharides undergo noticeable modifications leading to fruit softening. However, the polysaccharides involved in this softening process, the type of modifications occurring and their extent depend on the fruit species (Huber, 1984; Goulao and Oliveira, 2008). Modifications of pectin polysaccharides may result from two processes: solubilisation followed by depolymerisation. These two processes occur during softening of many fruits including tomato, avocado, melon and papaya (Brummell and Labavitch, 1997; Rose et al., 1998; Paull et al., 1999; Wakabayashi et al., 2000). In contrast, in softening apple and strawberry, the solubilisation of pectin is not followed by depolymerisation (Huber, 1983; Yoshioka et al., 1992). Similarly, softening of many fruits including tomato, avocado and melon is correlated with hemicelluloses degradation; while for other fruits such as apple or papaya, hemicelluloses do not undergo any significant degradation during softening 
(Percy et al., 1997; Manrique et al., 2004). In the case of safou, our previous investigations demonstrated that ripening process is accompanied by increasing solubilisation of pectin, the softening stage being characterized by significant pectin degradation. Cellulose and hemicelluloses did not undergo any visible modifications (Ella Missang et al., 2001a; 2001b; 2004). These investigations were

\section{MATERIAL AND METHODS}

Material: Three safou cultivars were selected randomly in home gardens throughout Masuku-Franceville city (southeast of Gabon). Fruits were picked at different stages of ripeness within a period of three months (from February to April 2006), transported carefully in the perforated bags to the laboratory and sampled according to the experimental design. performed using a single safou tree and without varying, several factors commonly considered to affect safou softening. Following these investigations, now this study is on the changes in safou texture and pectin fractions as affected by various factors including safou cultivar, ripening stage, picking mode, packaging mode and storage temperature.

Experimental design: Five factors were studied: cultivar, ripeness stage, picking mode, packaging mode and storage temperature. All factors had three levels. Three safou cultivars, phenotypically different regarding their fruits morphological traits, were selected (Table 1).

Table 1: Fruit morphological characteristics for the three cultivars

\begin{tabular}{l|c|c|c|c}
\hline Cultivars & $\begin{array}{c}\text { mass } \\
(\mathbf{g})\end{array}$ & $\begin{array}{c}\text { length } \\
(\mathbf{m m})\end{array}$ & $\begin{array}{c}\text { width } \\
(\mathbf{m m})\end{array}$ & $\begin{array}{c}\text { Pulp thickness } \\
(\mathbf{m m})\end{array}$ \\
\hline Cultivar 1 & $22.84^{\mathrm{a}} \pm 3.44$ & $46.46^{\mathrm{a}} \pm 2.43$ & $29.65^{\mathrm{a}} \pm 1.84$ & $4.93^{\mathrm{a}} \pm 0.57$ \\
Cultivar 2 & $40.58^{\mathrm{b}} \pm 5.16$ & $66.40^{\mathrm{b}} \pm 3.85$ & $33.73^{\mathrm{b}} \pm 1.98$ & $5.32^{\mathrm{b}} \pm 0.44$ \\
Cultivar 3 & $49.48^{\mathrm{c}} \pm 5.21$ & $70.84^{\mathrm{c}} \pm 2.85$ & $36.58^{\mathrm{c}} \pm 2.47$ & $5.42^{\mathrm{b}} \pm 0.47$ \\
\hline
\end{tabular}

Values are means of 30 -fruits \pm Standard deviation. Different letters $a, b, c$, on same column indicate that values are significantly different at $p<0.05$

All morphological characteristics, determined using callipers, differed significantly between cultivars. For the ripeness stage, fruits were picked at mid-ripe stage (fruits showing about $50-75 \%$ purple colouration), at ripe stage (fruits uniformly purple in skin colour) and at over-ripe stage (fruits picked approximately one month after ripe stage). Three usual picking modes were selected: fruits picked manually without peduncle, fruits picked manually with peduncle and fruits picked by beating. For the packaging mode, some fruits were stored without packaging while the other fruits were stored either in perforated plastic packaging or in closed plastic packaging. For the temperature, three storage rooms were used: the first room was cooled at about $18^{\circ} \mathrm{C}$; the second room was at ambient temperature, about $28^{\circ} \mathrm{C}$; and the third room was warmed at about $36^{\circ} \mathrm{C}$ with electric heating. A factorial design of 81 modalities, corresponding to factor level combinations, was built in order to determine the main effects and the two-factor interaction effects. The three-factor interaction effects were assumed negligible.

Texture measurement: For each modality and for each storage time, two samples of five fruits were constituted for fruit texture assessment. Two samples were used to measure fruit texture on the day of picking. The other samples were stored according to the modality's conditions and fruit texture was measured every two days up to day 8 using two samples for each storage time. Fruit texture, expressed as softening index, was measured using a penetrometer (K19500, Koehler Instrument Company, INC, USA) equipped with a $47.5 \mathrm{~g}$ plunger. The softening index corresponds to the depth of penetration of the plunger in safou pulp. For each sample, twelve measurements were taken by fruit, uniformly spread along its surface area. The softening index of one sample thus corresponds to the average of 60 measurements taken on five fruits of the sample. Therefore, sample being in duplicate, value of softening index at each storage time corresponds to the average of the softening index of the two samples. After texture measurement, samples were used for cell-wall analyses.

Water loss measurement: For each modality, two samples of five fruits were constituted for water loss measurement. On the day of picking, the five fruits of each sample were weighed together, giving the mass of the samples at day 0 . Then after, they were stored 
together with samples used for texture assessment according to the modality's conditions. The mass of the two samples was then measured every two days up to day 8 . Water loss at each storage time corresponds to the difference between the initial mass at day 0 and the mass of the sample at the giving storage time. This difference was divided by initial mass then multiplied by 100 .

Cell-wall preparation and pectin extraction: Cell-wall, as alcohol-insoluble solids (AIS), was prepared only from modalities corresponding to samples at ripe stage, on the day of picking, at 4 days and at 8 days storage. After texture measurement, fruits were peeled and the seed discarded. Samples of about $12-23 \mathrm{~g}$ of safou parenchyma were crushed in 4 volumes of cold $96 \%$ ethanol then filtered through a G3 sintered-glass filter (Fry, 1998). The insoluble materials were extracted twice with $15 \mathrm{ml}$ boiling $96 \%$ ethanol then with $64 \%$ ethanol (about $30-40$ times with $15 \mathrm{ml}$ ) until the filtrate was sugarfree (negative reaction in phenol/sulphuric acid test) (Dubois et al., 1956). The residues were then defatted by washing extensively first with hexane then with methanol: chloroform (1:1, v: v). The alcohol-insoluble solids (AIS) were then air-dried overnight at $30^{\circ} \mathrm{C}$. For pectin extraction, about $300 \mathrm{mg}$ of AIS were treated three times $(16 \mathrm{~h}, 3 \mathrm{~h}$ and $3 \mathrm{~h}$ ) with $15 \mathrm{ml}$ of $0.05 \mathrm{M} \mathrm{CDTA}$ (cyclohexanediaminotetraacetic acid) ( $\mathrm{pH} 4.8)$ at $20^{\circ} \mathrm{C}$. The extracts were pooled, extensively dialysed against $0.1 \mathrm{M} \mathrm{NaCl}$ then against distilled water and freeze-dried to obtain CDTA-soluble pectins (CSP).

Analytical methods: Uronic acids were directly determined in the CDTA extracts before and after dialysis by $m$-hydroxydiphenyl assay using micro plate system (spectra max plus ${ }^{384}$, France) (Blumenkrantz and Asboe-

\section{RESULTS AND DISCUSSION}

Morphological features of the species of Safou under study: Table 1 outlines the average values of the morphological features of Safou at each stage of maturity. In Cultivar I, there was Safou with the smallest size. Their average weight $(22.84 \mathrm{~g})$ was significantly lower than those of the other cultivars $(p<0.05)$. The same applied to the length, diameter and thickness of their pulps. These values were smaller and significantly different from those in Cultivars 2 and 3 . In Cultivars 2 and 3, the average weights of the fruit were significantly different, $40.58 \mathrm{~g}$ and $49.48 \mathrm{~g}$ respectively $(p<0.05)$. In Cultivar 2 , they were of a medium size, while in Cultivar 3 , they have a bigger size. The length and the diameter of the fruits in the Cultivars were significantly different, but there were no significant differences between the thickness of the pulp of Cultivar 2 and Cultivar 3. Many studies have focused
Hansen, 1973). About $10 \mathrm{mg}$ of CDTA freeze-dried extracts were used to determine the neutral sugar composition. The individual neutral sugars were analysed by gas chromatography (capillary column of $30 \mathrm{~m} \times 0.25$ $\mathrm{mm}$ id, coated with DB225, $0.15 \mu \mathrm{m}$ film thickness; J \& W Scientific, Folsom, USA) at $215^{\circ} \mathrm{C}$, using hydrogen as carrier gas, after sulphuric acid hydrolysis (1M, 3 h, 100 ${ }^{\circ} \mathrm{C}$ ) and derivatization to alditol acetates (Englyst and Cummings, 1984). Neutral sugars were detected at $250^{\circ} \mathrm{C}$. Myo-inositol was used as internal standard.

Statistical analysis: A General Linear Model (GLM), that combined multiple linear regression and analysis of variance, was used to evaluate the effect of the factors and their interactions on safou softening. A general mean response of softening index was obtained by the following polynomial model:

$$
Y=b_{0}+\sum_{i=1}^{k} b_{i} X_{i}+\sum_{i=1}^{k} \sum_{\substack{j=1 \\ j \neq i}}^{k} b_{i j} X_{i} X_{j}+\varepsilon
$$

where $Y$ is the estimated response, $b_{0}$ the model constant, $b_{i}$ and $b_{i j}$ the model coefficients reflecting the simple and interaction effects, respectively, $X_{i}$ the factors and $\varepsilon$ the residual error. The effect of each factor on softening index was studied at each storage time (from day 0 to day 8). Comparisons among the three levels of each factor were done using Fisher's Least Significant Difference (L.S.D.) test, the difference being considered significant for $p<0.05$. The analysis of variance was also used to evaluate the effect of each factor on cell-wall components. Statistical analyses were performed using Statgraphic software Plus v. 5.0 (Statistical Graphics Corp. Rockville, MD, USA) and XLstat 2007.6software.

on the variability of the morphological characteristics of Safou in various production zones including Nigeria, Cameroon, Congo, DRC (Democratic Republic of Congo) and Gabon. They concluded that there is a significant variation in the morphological characteristics of the fruit from one production zone to the other and from one tree to other within the same production zone ([Waruhiu, 1999; Waruhiu et al., 2004; Ondo-Azi et al., 2009). These morphological characteristics are the basis for the classification of Safou trees since the Dacryodes edulis species has not yet been clearly classified. Thus, research on safou trees in Central African conducted by Silou et al. (2002) classified the Dacryodes edulis species into three types: Type I, trees with small fruits (weight $<30$ g); Type II, trees with medium size fruits (weight between 30 and $60 \mathrm{~g}$ ); and Type III, trees with big size fruit 
(weight $>70 \mathrm{~g}$ ). The same classification was suggested by Ondo- Azi et al. (2009) on Franceville Safou tree in Gabon. In addition to the size of the fruit, other classification criteria such as the colour of the skin and the pulp, the uniformity of the colour of the skin at full maturity and the level of acidity were added by Ndindeng et al. (2008). They argued that the species could be classified into 9 groups with a group of unclassified species using their criteria. These findings illustrate the complexity of classifying Safou trees using the morphological characteristics of their fruits. In addition, no studies have been conducted using the most reliable criteria such as genetic markers to confirm that the identified morphological classes correspond indeed to varieties of Dacryodes edulis. Given the lack of information on the classification of Dacryodes edulis, this study will consider the selected trees as Cultivars and classified them into three groups using the main difference in their morphological characteristics, namely their weight:

- Cultivar 1: small size,

- Cultivars 2: medium size,

- Cultivars 3: big size.

Effects of the factors on the texture of the pulp of Safou: Probabilities $P$ of the key effects of the factors and the interactions between the various factors on the texture of the pulp of Safou: Table 2 summarizes the effects of each factor and of the combination of pairs of factors. The Cultivar effect played a significant role in the softening process throughout the storage. Temperature and storage method also had a very significant effect throughout the storage period $(p<0.0001)$. The level of maturity also had a significant effect on softening the fruit at the harvest, on the $6^{\text {th }}$ and $8^{\text {th }}$ day of storage. The effects of pairs of factors (Table 2 ) also revealed that:

- Interaction between the cultivar and the maturity stage is very significant on the day of harvest and on the $8^{\text {th }}$ day of storage;

- Interaction between the cultivar and the storage temperature is significant on the $2^{\text {nd }}$ and $4^{\text {th }}$ days of storage;

- Interaction between the harvesting method and the storage method is significant only on the $8^{\text {th }}$ day of storage;

- Interaction between the harvesting method and the storage temperature is significant on the $4^{\text {th }}$ and $8^{\text {th }}$ days of storage;

- Interaction between the temperature and storage method is highly significant throughout the storage;

Table 2: P-values of individual and two-factor interaction effects on softening index

\begin{tabular}{|c|c|c|c|c|c|}
\hline \multirow[b]{2}{*}{ Factors } & \multicolumn{5}{|c|}{ Storage time } \\
\hline & 0 day $^{*}$ & 2 days & 4 days & 6 days & 8 days \\
\hline Cultivar & $<0.0001$ & 0.0398 & 0.0068 & 0.0438 & 0.0780 \\
\hline Ripeness stage & $<0.0001$ & 0.7842 & 0.7260 & 0.0066 & 0.0044 \\
\hline Picking mode & 1.0000 & 0.5151 & 0.1414 & 0.7254 & 0.4787 \\
\hline Packaging mode & - & $<0.0001$ & $<0.0001$ & $<0.0001$ & $<0.0001$ \\
\hline Storage temperature & - & $<0.0001$ & $<0.0001$ & $<0.0001$ & $<0.0001$ \\
\hline Cultivar x Ripeness stage & $<0.0001$ & 0.2142 & 0.1043 & 0.2826 & 0.0315 \\
\hline Cultivar x Picking mode & - & 0.5387 & 0.3747 & 0.6218 & 0.7970 \\
\hline Cultivar x Packaging mode & - & 0.0513 & 0.1046 & 0.4457 & 0.7062 \\
\hline Cultivar $x$ Storage temperature & - & 0.0181 & 0.0086 & 0.9593 & 0.6723 \\
\hline Ripeness stage $\mathrm{x}$ Picking mode & - & 0.2847 & 0.1675 & 0.3054 & 0.7439 \\
\hline Ripeness stage x Packaging mode & - & 0.4397 & 0.2516 & 0.1253 & 0.7924 \\
\hline Ripeness stage $\mathrm{x}$ Storage temperature & - & 0.8242 & 0.4049 & 0.2984 & 0.1239 \\
\hline Picking mode x Packaging mode & - & 0.5145 & 0.1144 & 0.7470 & 0.0120 \\
\hline Picking mode $\mathrm{x}$ Storage temperature & - & 0.4445 & 0.0178 & 0.6224 & 0.0368 \\
\hline Packaging mode $\mathrm{x}$ Storage temperature & - & $<0.0001$ & $<0.0001$ & $<0.0001$ & $<0.0001$ \\
\hline
\end{tabular}

Significant values in bold, $\left({ }^{*}\right) 0$ day corresponds to values on the day of picking

These findings indicate that, temperature and storage method are the two major factors that significantly influence the texture of Safou during their storage. Cultivar is the third factor with a significant influence on the texture of the pulp. Regarding the maturity, the significant effect observed during the harvest implies that the softening index of the fruit substantially changes on the tree from a moderately matured stage to a very mature stage. However, the maturity as well as the 
method of harvest does not affect the texture of the pulp during storage.

Variation of softening index based on cultivar: Figure 1 shows the softening index of the fruit at the harvest for the three-targeted cultivars. Cultivar 2, medium size had the highest softening index $(0.85 \mathrm{~mm})$ and therefore the lowest firmness; it was followed by Cultivar 1. Cultivar 3 with the biggest size had the lowest softening index (0.69 $\mathrm{mm}$ ) and therefore the best firmness. The firmness of Safou at harvest varies significantly from a cultivar to the other regardless of the size of the fruit. These findings differ from the characteristics of many fruits such as apple, strawberry and blueberry which firmness at harvest, also known as initial firmness, decreases with the size of the fruit (Ourecky and Bourne, 1968; Ballinger et al., 1973; Blanpied et al., 1978).

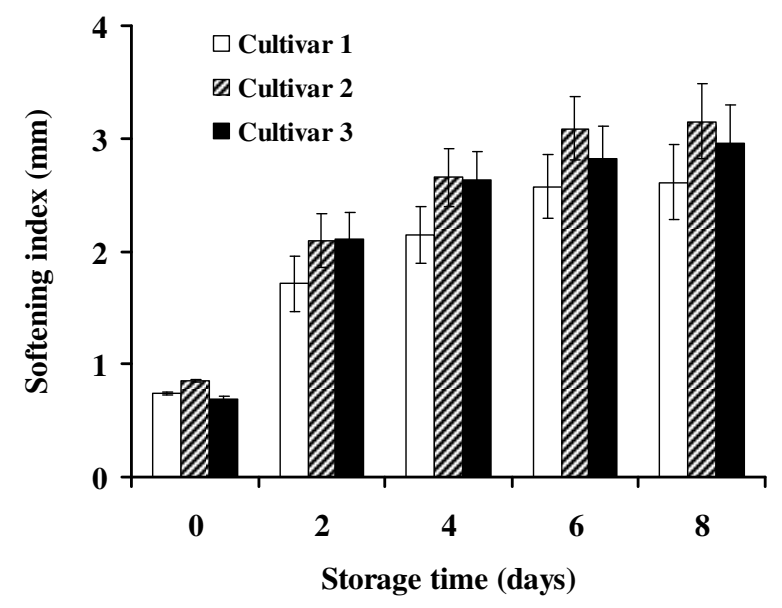

Figure 2: Effect of cultivar on softening index of safou during storage

The change in the softening index of the three cultivars during storage is recorded in Figure 2. The highest softening speed and softening index have been recorded with Cultivar 2 and 3 , which had the biggest fruits. However, the fruits in Cultivar 1 soften more slowly as compared to those in other cultivars. These results indicate that the softening speed of Safous increases with their size. This is contrary to the findings of Silou et al. (2007) which concluded that the softening speed of Safou does not depend on their size. Several studies on various fruits such as peach, tomato, banana and apple have already established that the evolution of texture during storage depends on the cultivar (Kader et al., 1982; De Ketelaere et al., 2004; Salvador et al., 2007). These results were confirmed by studies conducted on transgenic plant strains, which have clearly established that, one of the main factors that determine the texture of a fruit is the Cultivar (Schuch et al., 1991; Brummell et al., 2002). The Safou trees used in this study were grown from seeds hence, genetically different. It could be assumed that the cultivar is similar to the predefined groups of Silou et al. (2002) and Ondo-Azi et al. (2009) according to the size of the fruits. Thus, in the Safou, smaller fruits have a better postharvest preservation potential.
Variation of the softening index based on the method of storage and temperature of storage: Figure 3 shows the average softening indexes as a function of the temperature and the storage method. This is the main interaction with a daily highly significant effect during the storage. On the second day of storage (D2), for fruits in closed packaging, the average softening index increased linearly as a function with the temperature. It increased from $0.66 \mathrm{~mm}$ at $18{ }^{\circ} \mathrm{C}$ to $7.58 \mathrm{~mm}$ at $36^{\circ} \mathrm{C}$. However, the average index for fruits stored with no packaging or with a perforated packaging hardly changes with temperature. It remained the same for the two storage methods: $0.8-1 \mathrm{~mm}$ without packaging and 0.7-1.1 mm with perforated packing. At D4, the average softening index of fruits in closed containers still increased significantly but not linearly with the temperature $(0.73$ $\mathrm{mm}$ at $18^{\circ} \mathrm{C}$ to $7.13 \mathrm{~mm}$ at $36^{\circ} \mathrm{C}$ ). The softening index increased sharply between $18^{\circ} \mathrm{C}$ and $28^{\circ} \mathrm{C}$ and much less between 28 and $36^{\circ} \mathrm{C}$. For fruits with no packaging and those in perforated packaging, there was a slight increase in the softening index between $18^{\circ} \mathrm{C}$ and $28^{\circ} \mathrm{C}$ followed by a slight decrease. Softening indices obtained for fruits with no packaging were $0.68 \mathrm{~mm}$ and $1.3 \mathrm{~mm}$, respectively at $18^{\circ}$ and $36^{\circ} \mathrm{C}$. These are identical to those obtained with perforated packaging. Results of D6 and D8 were very similar. For fruits stored in closed 
packaging, the average softening index increased sharply between $18^{\circ} \mathrm{C}$ to $28^{\circ} \mathrm{C}$ and much less between $28^{\circ} \mathrm{C}$ and $36^{\circ} \mathrm{C}$. For fruits stored with no packaging and those with perforated packaging, there was a significant increase in the softening index between the first two temperatures followed by a sharp decrease before reaching lower values than those obtained at $18^{\circ} \mathrm{C}$.

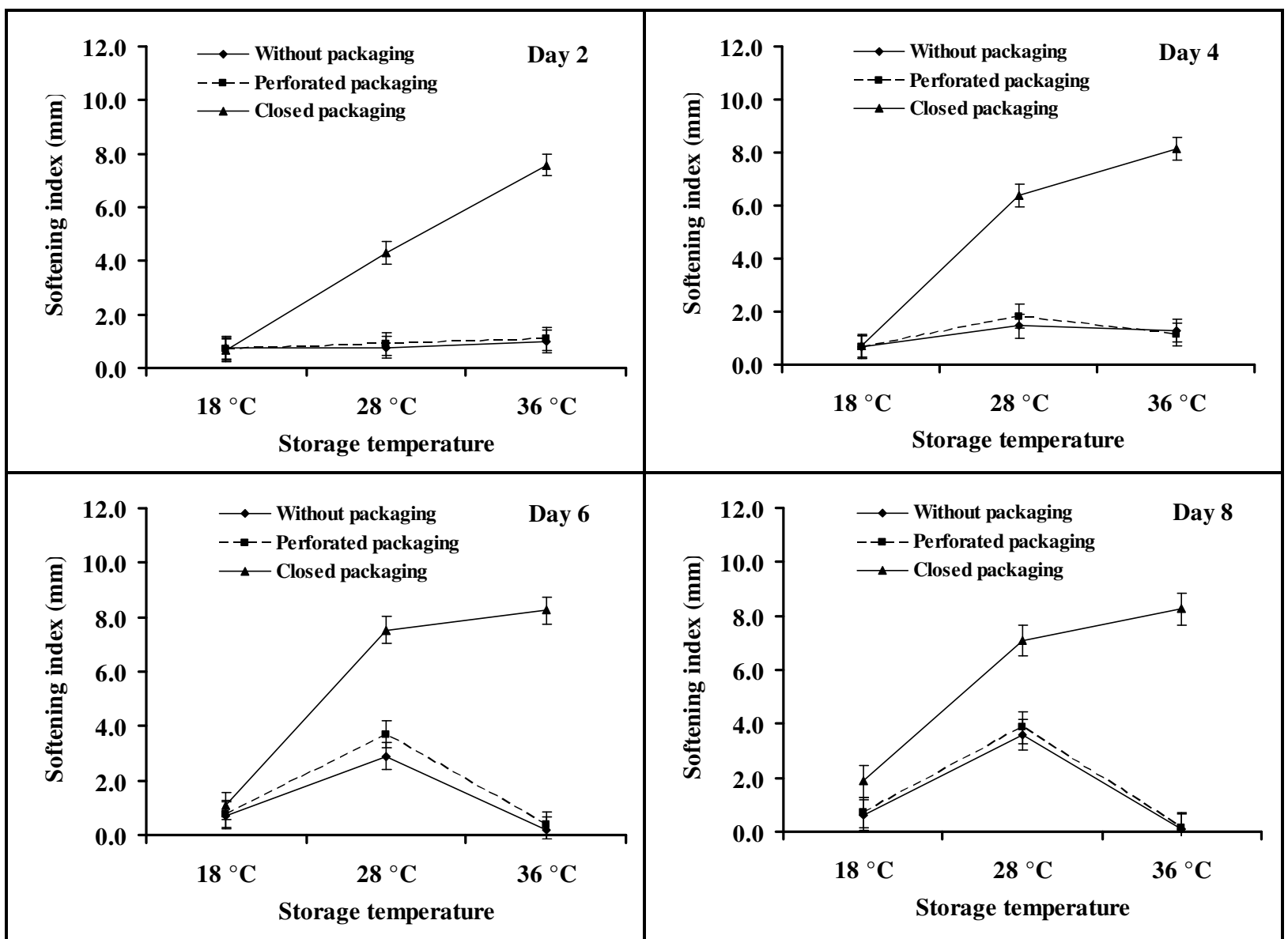

Figure 3: Effect of interaction of temperature and mode of packing on safou texture.

These findings indicate that Safous are best stored without packaging or in perforated packaging. Storing Safou in a closed packaging accelerates significantly its softening process and thus its post-harvest spoilage. The increase in the speed of the softening process in a closed packaging is probably due to the accumulation of ethylene following the restriction of free movement of gas through the plastic packaging. Indeed, several studies have clearly demonstrated that ethylene accelerates the softening process of fruits by activating the transcription of the enzymes responsible for degrading plant cell-wall (Brummell, 2005; Bennett and Labavitch, 2008). To understand what happened to safou in perforated packing and without packing conditions, the loss of weight following the dehydration of the Safou was monitored in the three cultivars under different conditions of the experimental plan. Table 3 shows the dehydration rate during storage at each temperature in the three cultivars and in different types of packaging. The loss of weight of the fruit stored with no packaging or with a perforated packaging worsens with temperature and the duration of storage. The highest level of dehydration occurred at 36 ${ }^{\circ} \mathrm{C}$ for both types of packaging on D8. There was virtually no dehydration at $18^{\circ} \mathrm{C}$ in closed packaging. At $28^{\circ} \mathrm{C}$ and $36^{\circ} \mathrm{C}$, dehydration was minimal. Safous stored with no packaging or with perforated packaging have the same dehydration patterns, which are completely different from those of fruits stored in closed packaging. 
Dossou et al, J. Appl. Biosci. 2018 Relationship between texture and cell-wall components of safou (Dacryodes edulis (G. Don) H.J. Lam) fruits at different storage conditions

Table 3: Water loss during storage under different temperatures and packaging modes

\begin{tabular}{|c|c|c|c|c|c|c|c|c|c|}
\hline \multirow{2}{*}{$\begin{array}{l}\text { Storage } \\
\text { time }\end{array}$} & \multicolumn{3}{|c|}{ Without packaging } & \multicolumn{3}{|c|}{ Perforated packaging } & \multicolumn{3}{|c|}{ Closed packaging } \\
\hline & $18^{\circ} \mathrm{C}$ & $28^{\circ} \mathrm{C}$ & $36^{\circ} \mathrm{C}$ & $18^{\circ} \mathrm{C}$ & $28^{\circ} \mathrm{C}$ & $36{ }^{\circ} \mathrm{C}$ & $18^{\circ} \mathrm{C}$ & $28^{\circ} \mathrm{C}$ & $36^{\circ} \mathrm{C}$ \\
\hline 2 & 6.8 & 7.1 & 24.0 & 6.4 & 6.0 & 18.9 & 0.4 & 0.4 & 0.1 \\
\hline 4 & 12.3 & 12.8 & 41.0 & 11.9 & 11.5 & 33.8 & 0.4 & 0.6 & 0.5 \\
\hline 6 & 17.7 & 18.4 & 48.1 & 17.4 & 17.3 & 43.5 & 0.5 & 0.9 & 1.6 \\
\hline 8 & 22.0 & 24.0 & 46.7 & 21.0 & 23.2 & 46.7 & 0.5 & 1.1 & 2.0 \\
\hline
\end{tabular}

Results are expressed by difference between initial fruit mass and fruits mass at the giving storage time divided by initial fruit mass then multiplied by 100 .

These results confirm that the tightening of Safou stored at $36^{\circ} \mathrm{C}$ with no packaging or with perforated packaging is caused by severe dehydration. Safous under such conditions go through a softening stage not noticeable by touch; they become directly dry and hard after a few days. When they are stored at $28{ }^{\circ} \mathrm{C}$ with no packaging or perforated packaging, they undergo a softening stage noticeable by touch. However, the softening phenomenon is mitigated by the tightening of Safous due to loss of water through transpiration. It was indeed noticed that the softening index on D8 at $28{ }^{\circ} \mathrm{C}$ of Safous with no packaging or with perforated packaging is about two times lower than that of those stored at the same temperature in a closed packaging with a very limited transpiration.

Table 4: P-values of individual and two-factor interaction effects on cell-wall components

\begin{tabular}{|c|c|c|c|c|}
\hline \multirow[b]{2}{*}{ Variables } & \multicolumn{2}{|c|}{ Individual effects } & \multicolumn{2}{|l|}{ Interaction effects } \\
\hline & Factors & $\mathbf{P}$ & Factors & $\mathbf{P}$ \\
\hline AIS & $\begin{array}{c}\text { Cultivar }(\mathrm{Cu}) \\
\text { Packaging mode }(\mathrm{Pa}) \\
\text { Storage temperature }(\mathrm{Te})\end{array}$ & $\begin{array}{l}<0,0001 \\
<0,0001 \\
<0,0001\end{array}$ & $\begin{array}{l}\text { Cultivar } \times \text { Packaging mode } \\
\text { Cultivar } \times \text { Storage temperature } \\
\text { Packaging mode } \times \text { Storage temperature }\end{array}$ & $\begin{array}{c}0,019 \\
0,001 \\
<0,0001\end{array}$ \\
\hline CSP & $\begin{array}{c}\text { Cultivar }(\mathrm{Cu}) \\
\text { Packaging mode }(\mathrm{Pa}) \\
\text { Storage temperature }(\mathrm{Te})\end{array}$ & $\begin{array}{l}0,001 \\
0,064 \\
0,006\end{array}$ & $\begin{array}{l}\text { Cultivar x Packaging mode } \\
\text { Cultivar } x \text { Storage temperature } \\
\text { Packaging mode } x \text { Storage temperature }\end{array}$ & $\begin{array}{l}0,104 \\
0,060 \\
0,554\end{array}$ \\
\hline Gal. $A_{1}$ & $\begin{array}{c}\text { Cultivar }(\mathrm{Cu}) \\
\text { Packaging mode }(\mathrm{Pa}) \\
\text { Storage temperature }(\mathrm{Te})\end{array}$ & $\begin{array}{l}<0,0001 \\
<0,0001 \\
<0,0001\end{array}$ & $\begin{array}{l}\text { Cultivar x Packaging mode } \\
\text { Cultivar } x \text { Storage temperature } \\
\text { Packaging mode } \times \text { Storage temperature }\end{array}$ & $\begin{array}{c}0,002 \\
0,0001 \\
0,045\end{array}$ \\
\hline Gal. $A_{2}$ & $\begin{array}{c}\text { Cultivar }(\mathrm{Cu}) \\
\text { Packaging mode }(\mathrm{Pa}) \\
\text { Storage temperature }(\mathrm{Te})\end{array}$ & $\begin{array}{l}0,200 \\
0,993 \\
0,482\end{array}$ & $\begin{array}{l}\text { Cultivar } x \text { Packaging mode } \\
\text { Cultivar } x \text { Storage temperature } \\
\text { Packaging mode } x \text { Storage temperature }\end{array}$ & $\begin{array}{l}0,907 \\
0,002 \\
0,813\end{array}$ \\
\hline Rha & $\begin{array}{c}\text { Cultivar }(\mathrm{Cu}) \\
\text { Packaging mode }(\mathrm{Pa}) \\
\text { Storage temperature }(\mathrm{Te})\end{array}$ & $\begin{array}{l}<0,0001 \\
<0,0001 \\
<0,0001\end{array}$ & $\begin{array}{l}\text { Cultivar } x \text { Packaging mode } \\
\text { Cultivar } x \text { Storage temperature } \\
\text { Packaging mode } \times \text { Storage temperature }\end{array}$ & $\begin{array}{l}0,104 \\
0,578 \\
0,077\end{array}$ \\
\hline Ara & $\begin{array}{c}\text { Cultivar }(\mathrm{Cu}) \\
\text { Packaging mode }(\mathrm{Pa}) \\
\text { Storage temperature }(\mathrm{Te})\end{array}$ & $\begin{array}{l}<0,0001 \\
<0,0001 \\
<0,0001\end{array}$ & $\begin{array}{l}\text { Cultivar } \times \text { Packaging mode } \\
\text { Cultivar } x \text { Storage temperature } \\
\text { Packaging mode } \times \text { Storage temperature }\end{array}$ & $\begin{array}{c}0,008 \\
0,0001 \\
0,003\end{array}$ \\
\hline Gal & $\begin{array}{c}\text { Cultivar }(\mathrm{Cu}) \\
\text { Packaging mode }(\mathrm{Pa}) \\
\text { Storage temperature }(\mathrm{Te})\end{array}$ & $\begin{array}{c}<0,0001 \\
0,140 \\
0,114\end{array}$ & $\begin{array}{l}\text { Cultivar x Packaging mode } \\
\text { Cultivar x Storage temperature } \\
\text { Packaging mode } \mathrm{x} \text { Storage temperature }\end{array}$ & $\begin{array}{l}0,011 \\
0,004 \\
0,710\end{array}$ \\
\hline
\end{tabular}

AIS: Alcohol insoluble solids, CSP: CDTA soluble pectins, Gal.A A $_{1}$ Galacturonic acid in CSP extracts before dialysis, Gal..A ${ }_{2}$ Galacturonic acid in CSP extracts after dialysis, Rha: Rhamnose, Ara: Arabinose, Gal: Galactose.

Significant values in bold 
Changes in the plant cell wall during storage: The analysis of the texture showed that the three factors, which significantly influence the texture of the pulp of Safou during its storage, are the cultivar, and especially the storage method as well as the temperature. The impact of these three factors were investigated especially their main impact and interactions on the composition of the wall during storage including the MIA content, CSP yields, pectin monosaccharides content (rhamnose, arabinose and galactose). Table 4 outlines the results of the variance analysis. Three factors had a highly significant effect on MIA ( $p<0.0001)$ : galacturonic acid from non-dialyzed CSP extracts (Gal.A1), rhamnose and arabinose. CSP yield was significantly influenced by the cultivar and the storage temperature; the storage method seemed to have no significant effects on this parameter. Only the cultivar had a significant effect on the galactose $(p<0.0001)$. No significant effect was observed in galacturonic acid from dialyzed CSP extracts (Gal.A2).The effects of the interaction between the factors on the composition of the wall were also studied. Table 4 presents the results of the variance analysis. The effects of the three interactions were significant on the MIA content; the galacturonic acid content from non-dialyzed CSP extracts (Gal.A1) and arabinose. Galactose was significantly influenced only by interactions involving the cultivar. Finally, for the other parameters, only one effect had a significant effect on the galacturonic acid after dialysis (Gal.A2); no significant effect was recorded for rhamnose.

Effect of the Cultivar: These results suggest that depending on the cultivar, the storage of Safous may lead to a significant modification in the contents of components of the wall cells of the fruit while no significant differences were observed on the harvest day. They also indicate that the walls of the three cultivars undergo relatively important modifications hence their different reactions during storage. This assumption is backed by Figure 4, which presents the variation in pectin monosaccharide of CSP during storage for each cultivar. For Cultivar 1 with the lowest softening speed, the galacturonic acid content (Gal.A1) decreased slightly and gradually between the harvest day (D0) and D8. However, in Cultivars 2 and 3 , which had the same postharvest softening speed, the Gal.A1 contents on D4 and D8 were significantly lower than on D0. The decrease in the galacturonic acid content of the CSP during storage was caused by the degradation of pectic polymers. Thus, pectin in Cultivars 2 and 3 undergo more degradation than in Cultivar 1.

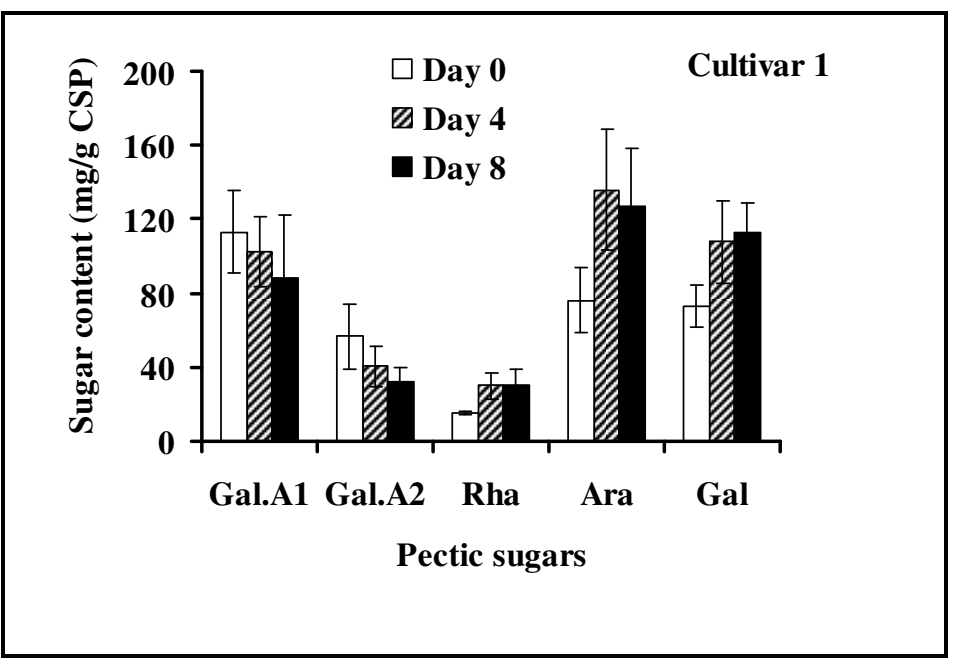




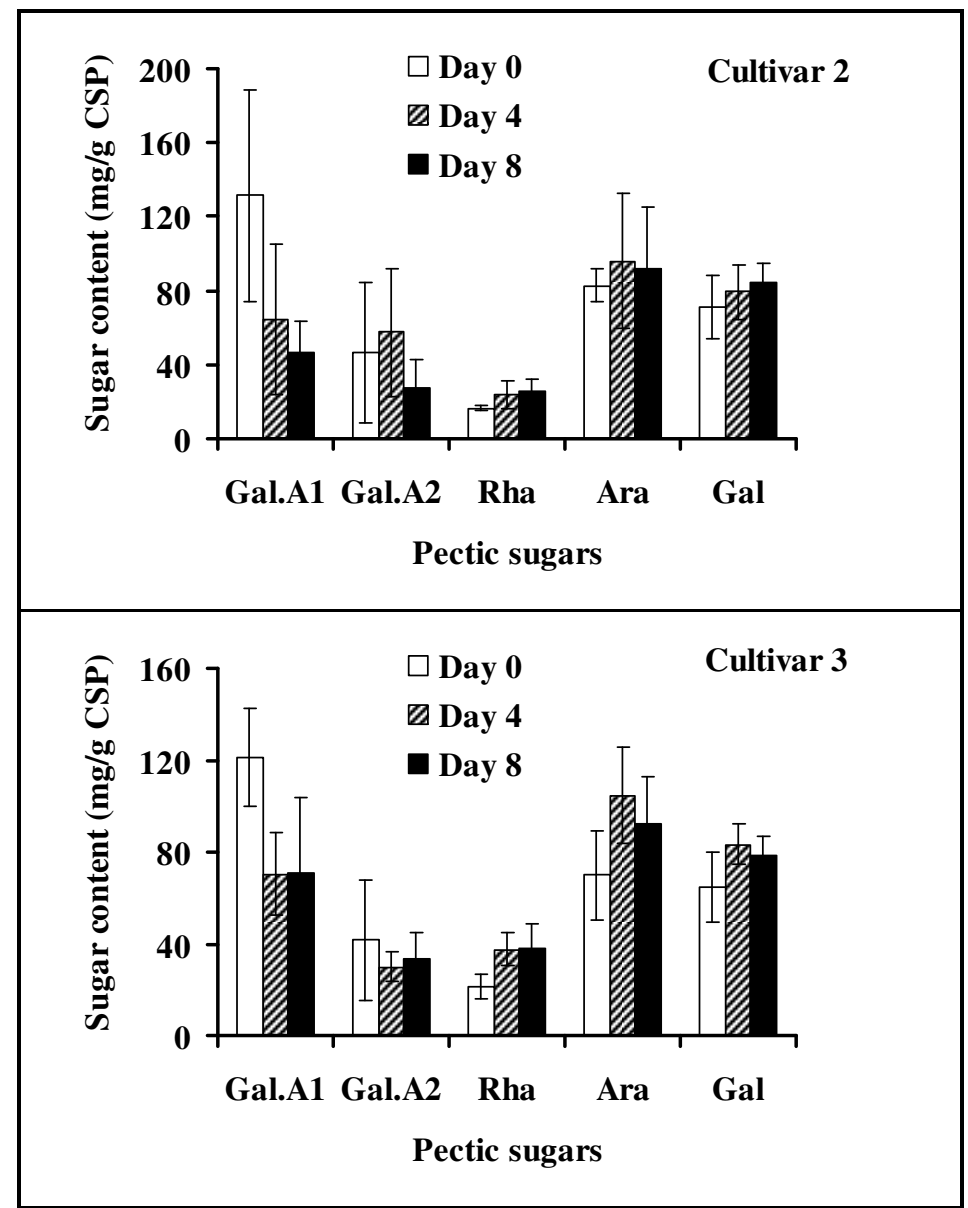

Figure 4: Effect of cultivar on the variation of safou pectic sugars

Moreover, the decrease in the galacturonic acid content is accompanied by an increase in rhamnose. This indicates that the degradation of pectin mainly occurred in homogalacturonan regions resulting in the enrichment of CSP extract into rhamnogalacturonan polymers. The increased content of arabinose and galactose D4 and D8 seem to confirm these findings. In fact, rhamnogalacturonanspectic regions are highly connected by arabinan, galactan and arabinogalactan side-chains commonly referred to as "hairy or bristling regions" (Keegstra et al., 1973; Ishii et al., 1989). The analysis of CSP of Safou pulp during storage has already been performed by Ella Missang et al. (2001b). Their fractionation by size exclusion chromatography showed the presence of two major fractions: a homogalacturonan fraction which molecular weight decreased progressively during storage and a rhamnogalacturonan fraction which proportion increased progressively during storage.

Effect of the interaction between method of storage and storage temperature: Figure 5, presents how the method of storage and the storage temperature impact on the parietal components. The contents of MIA are similar for Safou stored in perforated packaging or with no packaging regardless of the temperature: the highest levels of MIA were recorded at $36^{\circ} \mathrm{C}$ and the lowest at 28 ${ }^{\circ} \mathrm{C}$. When stored in closed packaging, there was a significant drop in the content of MIA as compared to the other two storage methods. Furthermore, the MIA content decreased slightly with the increase in temperature. Both Safou stored with perforated packaging and with no packaging had the same level of Galacturonic acid. The highest level of Gal.A1 content was recorded at $18{ }^{\circ} \mathrm{C}$ and the lowest at $28^{\circ} \mathrm{C}$. 


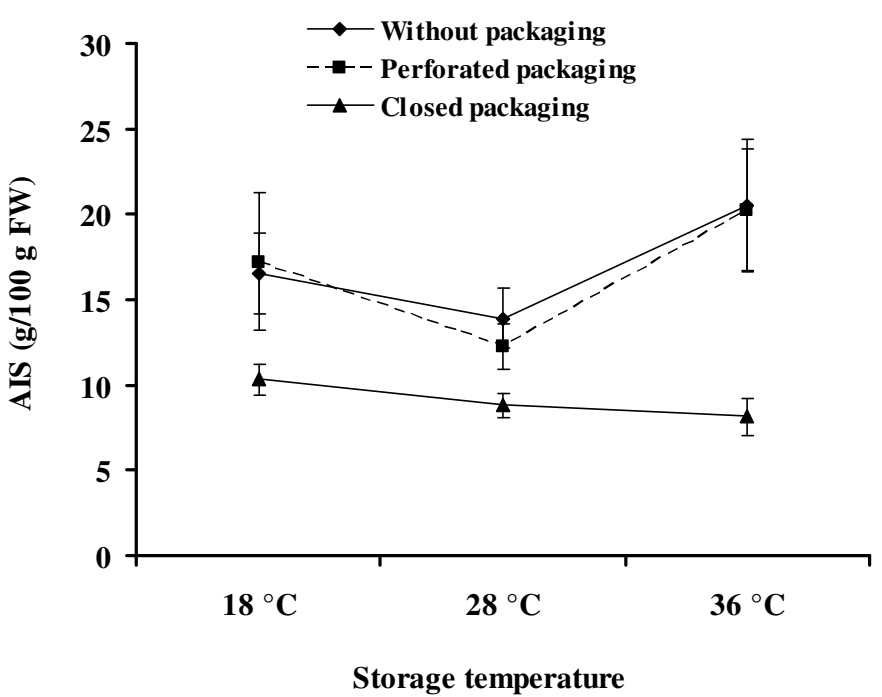

Figure 5: Effect of interaction of temperature and packing on safou AIS

The content of Gal.A1 in closed packaging remained relatively high at $18^{\circ} \mathrm{C}$ but drops significantly at $28^{\circ} \mathrm{C}$ and $36{ }^{\circ} \mathrm{C}$ (Figure $6 \mathrm{~A}$ ). Finally, the levels of arabinose were lower at $18^{\circ} \mathrm{C}$ than at $28^{\circ} \mathrm{C}$ and $36^{\circ} \mathrm{C}$, regardless of the storage method. However, there were only slight differences between the levels in Safous stored with perforated packaging and with no packaging but there were significant differences with those in closed packaging (Figure 6C). These results confirm that the high levels of MIA at $36{ }^{\circ} \mathrm{C}$ in Safou stored with perforated packaging and with no packaging were related to the partial dehydration of the fruit and the MIA is associated with the relatively dry weight. When the fruits undergo excessive softening at the same temperature in closed packaging, the MIA content dropped considerably following the degradation of pectin and oligogalacturonides soluble in alcohol during the preparation of the parietal material.

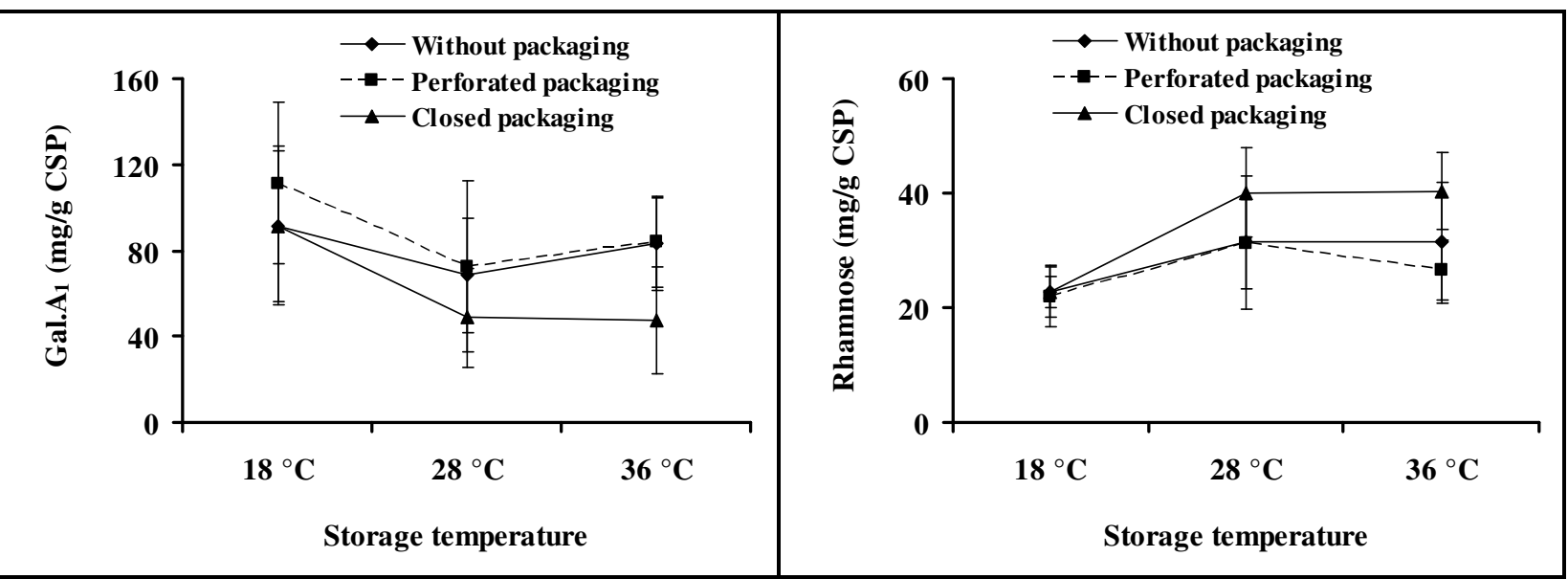




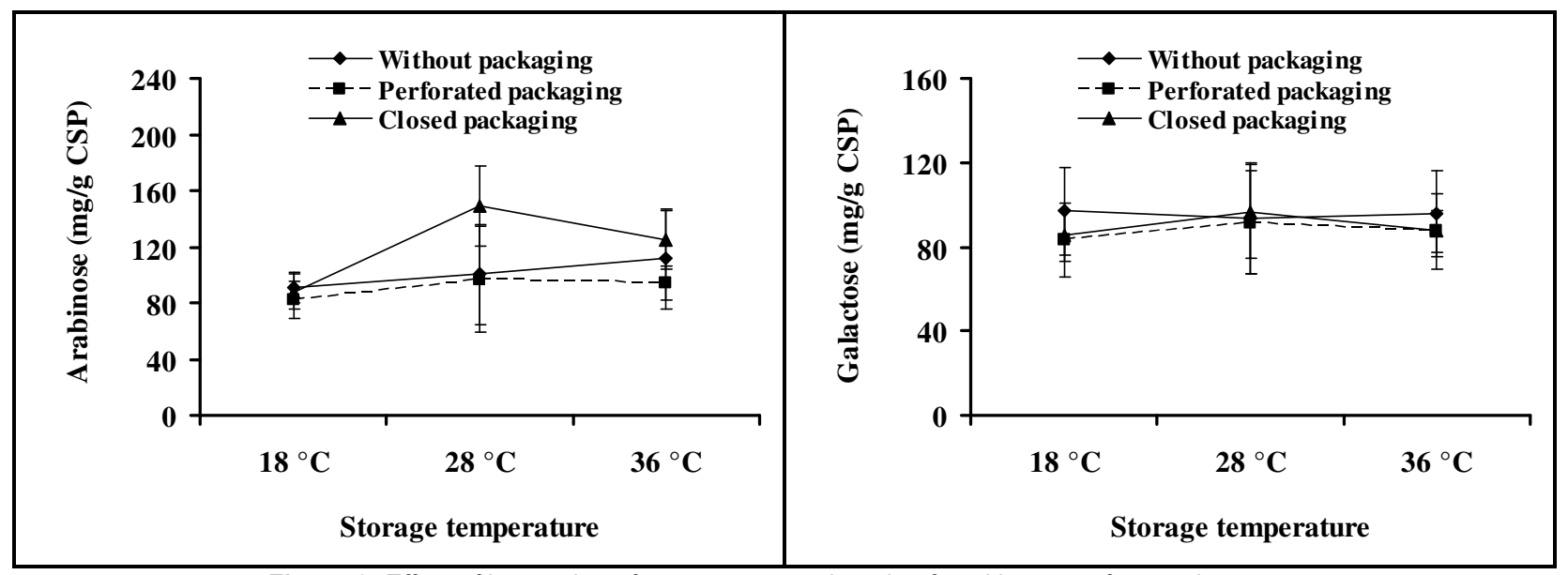

Figure 6: Effect of interaction of temperature and mode of packing on safou pectic sugars

Relation between texture and parietal components: Table 5 shows the matrix of the relation between the index of softening and the parietal components. The softening index is strongly and negatively correlated with the MIA content $(R=-0.657)$, which implies that the greater the softening index, the lower the MIA content. This applies to both the harvest day and the storage period. In fact, on the harvest day, cultivar 2 with the highest average softening index had the lowest level of MIA (Figure4).

Table 5. Pearson's correlation coefficients between softening index, yields of AIS and CSP and pectic sugars in safou pulp

\begin{tabular}{l|c|c|c|c|c|c|c|c}
\hline Variables & SI & AIS & CSP & Gal.A A $_{1}$ & Gal. A $_{2}$ & Rha & Ara & Gal \\
\hline SI & 1 & & & & & & & \\
AIS & -0.657 & 1 & & & & & & \\
PSC & 0.105 & -0.063 & 1 & & & & & \\
Gal. $A_{1}$ & -0.607 & $\mathbf{0 . 2 4 3}$ & $\mathbf{0 . 2 2 5}$ & 1 & & & & \\
Gal.A & -0.016 & 0.011 & 0.161 & 0.159 & 1 & & & \\
Rha & $\mathbf{0 . 6 2 9}$ & -0.167 & -0.086 & -0.535 & -0.270 & 1 & & \\
Ara & $\mathbf{0 . 4 7 3}$ & -0.245 & $\mathbf{0 . 2 1 2}$ & -0.193 & -0.177 & $\mathbf{0 . 4 8 1}$ & 1 & \\
Gal & 0.010 & 0.024 & 0.027 & 0.051 & -0.232 & 0.202 & $\mathbf{0 . 7 4 1}$ & 1 \\
\hline
\end{tabular}

SI: Softening index, AIS: Alcohol insoluble solids, CSP: CDTA soluble pectins, Gal.A1: Galacturonic acid content in PSC extracts before dialysis, Gal.A2: Galacturonic acid content in PSC extracts after dialysis, Rha: Rhamnose, Ara: Arabinose, Gal: Galactose Significant values in bold.

Thus, on the harvest day, the firmer the Safous (low softening index), the higher their MIA content. During storage, the relation between the softening index and the MIA content is much stronger. The analysis of much softened samples of fruits stored at high temperatures in a closed packaging revealed the lowest levels of MIA contents. As already studied in other fruits such as pawpaw and mango (Prasanna et al., 2003), the decrease in MIA content is caused by the extensive degradation of pectic polymers in softened samples. The degradation of pectin produces significant quantities of oligogalacturonides, which are eliminated during the elaboration of the parietal material, thus leading to the decrease in MIA content. The changes in the level of pectin in the wall are also reflected in the correlation between the softening index and the pectin monosaccharides from the CSP on one hand, and the correlations among pectin monosaccharides, on the other. Indeed, the softening index is significantly correlated with galacturonic acid (Gal.A1), rhamnose and arabinose; this correlation is negative with Gal.A1 ( $R=$ $0.607)$ and positive with rhamnose $(R=0.629)$ and arabinose $(R=0.473)$. These results indicate that the softer Safous are, the poorer the pectin extracted from their walls is in galacturonic acid, and the richer it is in rhamnose and arabinose and vice versa. Thus, in fresh not softened Safous, the walls are rather rich in homogalacturonans polymers with very high levels of 
galacturonic acid and very low levels of rhamnose. The softening process of Safous is accompanied with the degradation of the homoglacturonanes polymers as already observed by Ella Missang et al. (2001b). The degradation leads to the increase of the amount of rhamnoglacturonans, which are rich rhamnose polymers highly connected by side-chains of arabinan and galactan. Significant correlations between the pectin monosaccharides from the CSP confirm these changes. In fact, galacturonic acid (Gal.A1) is negatively correlated with rhamnose $(R=-0.535)$, indicating that the contents of these two monosaccharides evolve in opposite directions in pectin extracts during the softening process

\section{CONCLUSION AND APPLICATION OF RESULTS}

The texture of safou was significantly influenced during its storage by two major factors: temperature and method of storage, and there was a very significant interaction between these two factors. Moreover, the factors that were studied have significant effects on some cell wall components, including the MIA contents, the galacturonic acid of non-dialyzed CSP extracts (Gal.A1) and the arabinose. The key effects of the three factors as well as their interaction effects on the three components were

\section{REFERENCES}

Ballinger, W.E., Kushman, L.J., Hamann, D.D., 1973; Factors affecting the firmness of high bush blueberries. Journal of the American Society for Horticultural Sciences, 98, 583-587.

Bennett, B., Labavitch, J.M., 2008; Ethylene and ripening-regulated expression and function of fruit cell wall modifying proteins. Plant Science, $175,130-136$.

Blanpied, G.D., Bramlage, W.J., Dewey, D.H., LaBelle, R.L., Massey, L.M., Mattus, G.E., Siles, W.C., Watada, A.E., 1978; A standardized method for collecting apple pressure test data. New York's Food and Life Sciences Bulletin, 74

Blumenkrantz, N. and Asboe-Hansen, G., 1973; New method for quantitative determination of uronic acids. Analytical Biochemistry, 54, 484-489.

Brummell, D.A. and Labavitch, J.M., 1997; Effect of antisense suppression of endopolygalacturonase activity on polyuronide molecular weight in ripening tomato fruit and fruit homogenates. Plant Physiology, 115, 717725.

Brummell, D.A., 2005. Regulation and genetic manipulation of ripening in climacteric fruit. Stewart Postharvest Review, 3(1), 1-19. of Safous. Furthermore, rhamnose is significantly correlated with arabinose $(R=0.481)$ because of the high levels of these monosaccharides in the rhamnogalacturonans areas of pectins. The two monosaccharides of the side-chains of pectin, arabinose and galactose are also highly correlated $(R=0.741)$. The modification of the extracts of pectin during the softening process has been studied in some fruits. Our results are similar to those on fisheries and kiwi that show an increase of the pectic extracts in rhamnogalacturonans polymers after the degradation of homogalacturonans (Redgwell et al., 1990; Hegde and Maness, 1996).

significant. The rhamnose content was significantly influenced by each of these three factors. Only the cultivar and the interactions involving the cultivars have a significant effect on the galactose content. From these findings, pectic polymers undergo more or less significant degradation, depending on the cultivar and storage conditions. The homogalacturonans of pectin were degraded. These changes, which occurred in the level in the wall, have an impact on the texture of the Safous.

Brummell, D.A., Howie, W.J., Ma C., Dunsmuir, P., 2002; Postharvest fruit quality of transgenic tomatoes suppressed in expression of ripening-related expansin.Postharvest Biology and Technology, 25, 209-220.

De Ketelaere, B., Lammertyn, J., Molenberghs, G., Desmet, M., Nicolaï, B., De Baerdemaeker, J., 2004; Tomato cultivar grouping based on firmness evolution, shelf-life and variability during postharvest storage. Postharvest biology and technology, 34, 187-201.

Dubois, M., Gilles, K.A., Hamilton, J.K., Rebers, P.A. and Smith, F., 1956; Colorimetric method for determination of sugar and related substances. Analytical Chemistry, 28, 350-356.

Ella Missang C., Renard C.M.G.C., Baron A., Drilleau J.F., 2001b.; Changes in the pectic fraction of bush butter (Dacryodes edulis (G. Don, H.J. Lam)) fruit pulp and their evolution during ripening. Journal of the Science of Food and Agriculture, 81, 781-789.

Ella Missang, C., Renard, C.M.G.C. and Baron, A., 2004; Cell wall-degrading enzymes and changes in cell wall polysaccharides during ripening and storage of bush butter (Dacryodes edulis (G. 
Don) HJ Lam) fruit. Journal of Horticultural Science \& Biotechnology, 79 (5), 797-805.

Ella Missang C., Renard, C.M.G.C., Baron, A. and Drilleau, J-F., 2001a. Cell wall polysaccharides of bush butter (Dacryodes edulis(G. Don) HJ Lam) fruit pulp and their evolution during ripening. Journal of Science of Food and Agriculture, 81,773-780.

Englyst, H.N. and Cummings, J.H., 1984. Simplified method for the measurement of total non-starch polysaccharides by gas-liquid chromatography of constituent sugars as alditolacetates. Analyst, 109, 937-942.

Fry, S.C., 1988; The growing plant cell wall: chemical and metabolic analysis. Longman Scientific \& Technical, Harlow, UK.

Giovannoni, J., 2001; Molecular biology of fruit maturation and ripening. Annual Review of Plant Physiology and Plant Molecular Biology, 52, $725-749$

Goulao, L.F. and Oliveira, C.M., 2008; Cell wall modifications during fruit ripening: when a fruit is not the fruit. Trends in Food Science and Technology, 19, 4-25.

Hegde, S., Maness, N.O., 1996; Sugar composition of pectin and hemicellulose extracts of peach fruit during softening over two harvest seasons. Journal of the American Society for Horticultural Sciences, 121 (6), 1162-1167.

Huber, D.J., 1983. The role of cell wall hydrolysis in fruit softening. Horticultural Reviews, 5, 169-219.

Huber, D.J., 1984. Strawberry (Fragaria ananassa) fruit softening, the potential roles of polyuronides and hemicelluloses. Journal of Food Science, 49, 1310-1315.

Ishii, T., Thomas, J., Darvill, A., Albersheim, P., 1989; Structure of plant cell walls. XXVI. The walls of suspension-cultured sycamore cells contain a family of rhamnogalacturonan--like pectic polysaccharides. Plant Physiology, 89, 421-428.

Kader, A.A., Heintz, C.M., Chordas, A., 1982. Postharvest quality of fresh and canned clingstone peaches as influenced by genotypes and maturity at harvest. Journal of American Society for Horticultural Sciences, 107, 947-951.

Keegstra, K., Talmadge, K.W., Bauer, W.D., Albersheim, P., 1973. Structure of plant cell walls III.A model of suspension-cultured sycamore cells based on the inter-connections of macromolecular components. Plant Physiology, 51, 188-197.
Kengue, J. (1990); Le safoutier (Dacryodesedulis (G Don) HJ Lam). Thèse Doctorat 3ième cycle, Université de Yaoundé, Cameroun.

Kengue, J., 2002. Safou Dacryodes edulis G Don. International Centre for Underutilised crops. RPM Reprographics Chichester, England, 147p

Manrique, G.D. and Lajolo, F.M., 2004; Cell-wall polysaccharide modifications during postharvest ripening of papaya fruit (Carica papaya). Postharvest Biology and Technology, 33, 11-26.

Ndindeng, S.A., Bella-Manga, Kengue, J., Talle, Lewis, D.L., 2008; Quality standards for Dacryodes edulis (safou). Research Report $\mathrm{N}^{\circ} 5$. International Centre for Underutilised Crops, Colombo, Sri Lanka, $26 \mathrm{p}$.

Ondo-Azi, A.S., Ella Missang, C., Silou T., 2009; Classification of Dacryodes edulis (G. Don) H.J. Lam by using morphological and physical characteristics of the fruits: statistical approach. Forests, trees and livelihoods, 19(2), 99-109.

Ourecky, D.K., Bourne, M.C., 1968; Measurement of strawberry texture with an Instron machine. Proceedings of the American Society for Horticultural Sciences, 93, 317-325.

Paull, R.E., Gross, K. and Qui, Y., 1999; Changes in papaya cell walls during fruit ripening. Postharvest Biology and Technology, 16, 79-89.

Percy, A.E., Melton, L.D. and Jameson, P.E., 1997; Xyloglucan and hemicelluloses in the cell wall during apple fruit development and ripening. Plant Science, 125, 31-39.

Prasanna V., Yashoda H. M., Prabha T. N., Tharanathan R. N., 2003; Pectic polysaccharides during ripening of mango (Mangiferaindica $\mathrm{L}$ ). Journal of the science of food and agriculture vol. 83, no11, pp. 1182-1186.

Redgwell, R.J., Melton, L.D., Brasch, D.J., 1990; Wall changes in kiwifruit following post-harvest ethylene treatment. Phytochemistry, 20, 399407

Rose, J.K.C., Hadfield, K.A., Labavitch, J.M. and Bennett, A.B., 1998; Temporal sequence of cell wall disassembly in rapidly ripening melon fruit. Plant Physiology, 117, 345-361.

Salvador, A., Sanz, T., Fiszman, S.M., 2007; Changes in colour and texture and their relationship with eating quality during storage of two different dessert bananas. Postharvest Biology and Technology, 43, 319-325.

Schreckenberg, K., Degrande, A., Mbosso, C., BoliBaboulé, Z., Boyd, C., Enyong, L., 
Kanmegne, J. and Ngong, C., 2002. The social and economic importance of Dacryodesedulis (G. Don) H.J. Lam. In southern Cameroon. Forest Trees and Livelihoods, 12, 15-40.

Schuch, W., Kanczler, J., Roberston, D., Hobson, G., Tucker, G., Grierson, D., Bright S., Bird, C., 1991; Fruit quality characteristics of transgenic tomato fruit with altered polygalacturonase activity. HortScience, 12, 71-72.

Silou, T., Massamba, D., GomaManiongui, J., Maloumbi, G., Biyoko, S., 2007; Post-harvest losses by natural softening of safou pulp (Dacryodes edulis) in Congo-Brazzaville. Journal of Food Engineering, 79, 392-400.

Silou, Th., Rocquelin, Mouaragadja, I., G. and Gallon, G., 2002; Contribution of the characterization of safous (Dacryodes edulis) of Central Africa III. Chemical composition and nutritional characteristics of safou of Cameroon, the Congo-Brazzaville, the Congo-Kinshasa and Gabon .Rivista Italiana Delle Sostanze Grasse, 79, 177-182.
Wakabayashi, K., Chun, J.P. and Huber, D.J., 2000 ; Extensive solubilization and depolymerization of cell wall polysaccharides during avocado (Persea Americana) ripening involves concerted action of polygalacturonase and pectinmethylesterase. PhysiologiaPlantarum, 10, 345-352.

Waruhiu, A.N., 1999; Characterization of fruits traits towards domestication of an indigenous fruit tree of west and central Africa: A case of Dacryodes edulis in Cameroon. M.Sc. Thesis, University of Edinburgh, 58p.

Waruhiu, A.N., Kengue, J., Atangana, A.R., Tchoundjeu, Z., Leakey R.R.B., 2004; Domestication of Dacryodes edulis: 2. Phenotypic variation of fruit traits in 200 trees from four populations in the humid lowlands of Cameroon. Food, Agriculture \& Environment, 2, 340-346.

Yoshioka, H., Aoba, K. and Kashimura, Y., 1992; Molecular weight and degree of methoxylation in cell wall polyuronide during softening in pear and apple fruit. Journal of the American Society of Horticultural Science, 117, 600-606. 